\title{
Waste Scavenging and Its Contribution for Survival and Urban Recycling in Kota Kinabalu City, Sabah, Malaysia.
}

\author{
Mohammad Tahir Mapa, Jane C Powell, Abdul Hair Beddu Asis, Nordin Sakke and Aliakbar Gulasan \\ Geography Program, Faculty of Humanities, Art and Heritage, Universiti Malaysia Sabah, Malaysia
}

Received: 2019-02-12 Accepted: 2019-08-04

Keywords:

Scavengers,

Waste Management,

Recycling,

Landfill

Corespondent Email: herma@ums.edu.my

\begin{abstract}
High generation of solid waste has been identified as one factor contributing to the world's environmental problems. The decrease in suitable landfill sites and scarcity of natural resources is creating greater demand for remanufacturing and reuse. This study aims to examine the contribution and issues embedded in scavengers group to achieved high rate of recycling in waste management program. In order to answer the research objective, this research utilized in-depth interviews conducted with scavengers group. This study revealed scavenging activity is an important element in waste management with positive impact on the economic and environment. Therefore, to support this, the scavengers group need to be part of the government's attempt to realise its recycling objectives.
\end{abstract}

\section{Introduction}

Malaysia, with a total population of 30 million, is experiencing an increase in the generation and accumulation of waste. Solid waste management is one of the major environmental problems faced by the country's municipalities. The amount of waste generated in the country will continue to increase, not only with the increase in population and economic activities but also in terms of per capita generation rate. Local communities in the country generated about 5.2 million tons of waste in 1993. The national average of waste generation rate estimated for 1991-1993 was about $0.71 \mathrm{~kg} / \mathrm{capita} /$ day and increased to about $0.8 \mathrm{~kg} /$ capita/day in 2000 (Malaysia, 2001). About 17 million tonne of waste expected to be generated by Malaysian in the year 2020 (Mohamad Taha, 2018). In urban area waste generation increased 3\% annually due to urban migration, affluence and rapid development (Kashyap \& Visvanathan, 2014). The waste generated increases correspondingly with improvements to the standard of living and people's changing lifestyles. Increased quantities of waste in the area affect the efficiency of collection and disposal from a management point of view. About $95 \%$ of wastes collected by the local authority or private sector are disposed of into more than 300 landfills.

The informal collection of recyclable item performed by waste pickers is a complex and dynamic socioeconomic phenomenon. Between 2000 and 2012, the global informal recycling sector came into focus as the base of the industrial value chain (Scheinberg, 2012).The activities are largely found in less developed countries due to economic instability and illegal immigration. Informal recycling plays an important role for thousands of the urban poor in many third world cities as a source of income especiallysince the last global economic downturn (Dias, 2016). This sector has great potential for the reduction of the cost of cities' solid waste management (SWM) programs.

Early study in Dar es Salaam (Nigeria) indicate there are about 600 solid waste scavengers with approximately 109 of whom operate at Vingunguti dump site and at 14 different collection centers (Kaseva \& Gupta, 1996). In 2002 it was estimated that around 1500 men, women, and children were living and working at the Jam Chakro Karachi disposal site, in 2005 its grown to as many as 3000 , in 350 households mainly rural migrants from Sindh and Balochistan(Rouse, 2006). Reasons for settling around dumps are to ensure that scavengers can minimize their transportation costs, occupy land that may be undesirable to others and gain access to discarded materials that can be used as construction materials for their homes and thus save on housing costs (Agunwamba, 2003).

Informal sector participation in solid waste management has different dimensions in some third world countries. For example, in Indonesia the sector hires and manages neighborhood workers who provide door-to-door waste collection (Soerjani, 1984, Supriyadi et al., 2000). In Nairobi, Kenya, the sector collects waste from private homes (especially from middle and high income areas), industries and offices for disposal and recycling (Henry, Yongsheng, \& Jun, 2006). In Egypt, the existing informal system is recovering $80 \%$ of waste collected by the municipalities. In addition, seven to eight jobs are generated per ton of waste collected (Kamel, 2000). Recovery rates as high as $80 \%$ are 
achieved by the Zabbaleen in Egypt due to intensive manual sorting and their expertise at extracting waste with value (Wilson, Velis, \& Cheeseman, 2006).

Realizing the importance of this group, their activities at most dumpsites in third world countries have been integrated into normal landfill operations. This type of activity is in general the best method of waste recovery, with a high percentage of waste sorted every day. For example, approximately $25 \%$ of the $21,000 \mathrm{~m} 3$ of waste generated in Jakarta is recovered by this group, saving the city authorities $\$ 270,000-\$ 300,000$ per month (Soerjani, 1984). In Bantar Gebang final disposal site in Jakarta, the recycling rate of solid wastes collected by all scavengers at the site was estimated to be in the range of $2.8-7.5 \%$ of all solid wastes transported to the site or approximately $100 \mathrm{~kg}$ day per household on the net weight basis (Sasaki \& Araki, 2014). In China, Waste Pickers, Waste Merchants and Middle Men, collect on average 16, 311, and $890 \mathrm{~kg}$ of recyclables per day and capita respectively (Steuer, Ramusch, Part, \& Salhofer, 2017). In Laredo, Texas and Nuevo Laredo, Mexico, dumpsite scavengers recover approximately $75 \%$ of cans consumed by the area's population (Medina, 2000). Almost $90 \%$ of inorganic waste is recycled in the informal sector in Multan Pakistan. In Bangkok the total daily tonnage of recyclable garbage collected by waste pickers is estimated at 286 tonnes $(50-150 \mathrm{~kg} /$ person/day) or about $5 \%$ of the garbage collected by the city (Muttamara, 1994). The above findings suggest that waste scavenger activities should be acknowledged and incorporated formally into the recycling process of every local authority.

Although scavengers' activities seem to be suboptimal, their contribution is important to the economy of residents with respect to resource conservation and the creation of job opportunities. In Colombia, approximately $1 \%$ of the population, more than 50,000 families, earn their living from urban rubbish (Pacheco, 1994). Scavengers in Nigeria are reported to earn around $\$ 10.00$ from two days of sorting landfill and they are able to live on this income (Agunwamba, 2003). Muttamaraet al. (1994) found that scavengers in Bangkok Metropolitan Area can earn on average $£ 79.00$ a month. The waste pickers in Tucuman, Argentina earn approximately 1.75 times the minimum wage, almost entirely by collecting recyclable waste such as plastics (McBean, del Rosso, \& Rovers, 2005). Masocha (2006) concludes that by engaging in informal waste harvesting, some of the urban poor are able to eke out a living in an urban environment where economic opportunities are very limited. However, the scavenging activity has its own problems when it comes to total income generation. Scavengers' income is very low, although they are not the very poorest in society (Medina, 2000). Even in that situation the average monthly income of scavengers exceeds the official minimum wage, enabling them to support their families (Kaseva \& Gupta, 1996).

Even though studies have shown the significant contribution of scavenger groups there is still not enough recognition from the authorities. City governments need to establish a mechanism to recognize the continued contribution of this group, their importance in informal waste recovery and the fact that it provides a source of income for the poor. This highlight an indications that waste scavengers could be incorporated formally into the recycling process to become one of the main sources of recyclable material; using plastic waste as an example, they demonstrate that such recycling is economically viable. A study in Brazil revealed that even though recycling rates is considerhigher that is between $45 \%$ and $55 \%$, only $1 \%$ of it is accumulated selectively by the government and this demonstrating that recycling is mainly performed by waste-pickers (Tirado-Soto \& Zamberlan, 2013).

The aims of this study are to examine the contribution and issues embedded in scavengers group to achieved high rate of recycling in waste management program. This study is expected to provide accurate information on the activities of waste scavenging in the study area. Thus, the authorities can design solid waste management plan with take into account the ability of this group.

\section{The Methods}

The scope of this study is to identify the involvement of waste pickers in the collection of recyclable waste. The area selected for this study is Kota Kinabalu, the capital city of Sabah, Malaysia (figure 1). Kota Kinabalu is the focus of many economic activities. Therefore, solid waste production from most activities is expected to increase. Hence, the involvement of all stakeholders in the waste management sector needs to be improved so that the issues can be solved. Malaysia is one of the fastest growing countries in South East Asia. The study covers an area of $351 \mathrm{~km} 2$ and is divided into four types of land use, namely urban, suburban, rural, and marine (coastline and small islands). The Kota Kinabalu City Hall $(\mathrm{KKCH})$ administration area comprises four legislative areas; Kota Kinabalu, Inanam, Manggatal and Telipok. It is the administration seat and serves as the centre for education, communication and trade and commerce. In February 2000 Kota Kinabalu was declared a city, and became the first urban centre in Sabah to be given this status. At this time the name of Kota Kinabalu Municipal Council was automatically changed to $\mathrm{KKCH}$ reflect this change in status

The 2010 census shows that residents of Kota Kinabalu City are 452058 people (Department of Statistics Malaysia, 2010). The population of Kota Kinabalu is comprised of various ethnicities and races namely Bumiputera (70.4 percent), Chinese (27.4 percent), India (0.6 percent) and others (1.6 percent). Kota Kinabalu district recorded the highest population density of 598 persons per square kilometre. The population growth rate from 1990 to 2000 was 5.85\%, and Malaysian citizens comprised 82.3 percent of the total population. Kota Kinabalu, as the capital of Sabah, is the largest urban centre in the state. 


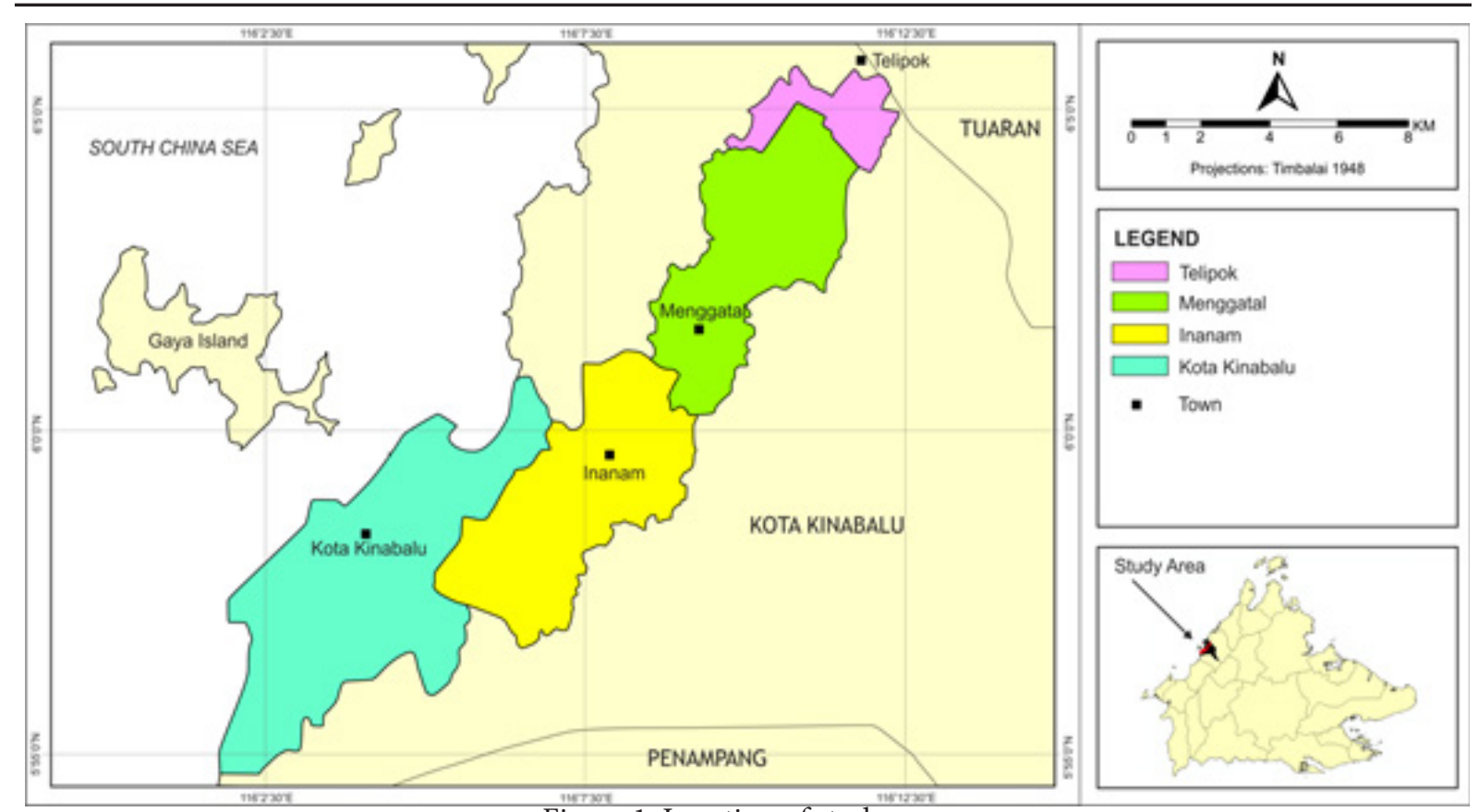

Figure 1. Location of study area

Data Collection

This research consisted of in-depth interviews conducted with key informants. The selection of interviewees was based on their ability to contribute information and useful views and positions. The informants who were most involved with the topic being studied were judged as most appropriate for an interview, therefore only individuals with day-to-day responsibility for waste management were interviewed. All the interviewees were closely involved with solid waste management and the recycling activity, so they had great familiarity with the field.

Most of the information regarding the activity of these sectors has not been research before. Thus to be enable research on this group, various areas were investigated on the assumption that this activity could be found there. Having identified a scavenger, the next step, before the interview took place, was to brief them regarding the purpose of the research. The interviews with these groups took place in locations such as landfill sites, city centers and housing and commercial areas, the landfill sites being the main locations. The interview questions employed in these interviews were unstructured but emphasized the importance of recycling, issues related to waste management and socio economic. These questions took the form of an ordinary conversation controlled by the interviewer in order to focus on specific topics.

\section{Data Analysis}

In this study, the interview data were transcribed and analysed manually since there were only a small number of interviews. The interviews were transcribed into the written form so that the data could be organised and managed. Transcription is the translation both of spoken to written language and of personal conversation to a text which can be read analytically. Interview analysis in this study consisted of listening to the tape recordings, extracting commonly recurring themes and transcribing them. The first stage of the process involves interpretation of the context drawn from the words said, the repetitions made and how the words were said. The next step is to read through the transcripts to identify themes and sub-themes. Finally the process was ended by summarising the key points from each interviewee, which is sufficient for the purposes of this study.

\section{Results and Discussion}

The total number of scavengers interviewed was thirty-five consists of twenty local scavengers, five foreigners (immigrants) and ten landfill scavengers. Almost $49 \%$ of those were male and 51\%, female. Their average age was 30.7, the youngest being nine years old and the oldest 66. In Malaysia there are four categories of informal collectors, namely full-time scavengers, the part-time municipal waste collection crew, institutional cleaners and market cleaners. Currently only two of these categories have been studied; the collection crew (municipal workers) and full-time landfill scavengers. These are groups that undertake separation and sorting, one of the most important components in recycling process. This study shows that those who working in this sector are belong to different socio-demographic and socio-economic background. Similar study found that both males and females of all age groups are collecting recyclables which most of them are migrants, minorities, and poor refugees (Kamran, Chaudhry, \& Batool, 2016).

\section{Socio Demographic of the Scavengers}

In this study 'local' scavenger refers to people who identify themselves as belonging to one of the ethnic 
groups in the study area. The socio-demographics of the local scavengers are presented in Table 1. In terms of age, more than $50 \%$ were between 15 and 35 years old, the youngest being 15 and the oldest 52 . The majority $(60 \%)$ had education up to secondary school level, while the remainder had no formal education. Most of the local scavengers were female (60\%), and the largest ethnic group involved in these activities was the Kadazan Dusun (65\%).

For the foreign scavengers, children aged between ten and twelve dominated the group. Because of their immigrant status most of them were fearful of being interviewed, as they assumed that the interviewers came from the government. For this reason only five respondents agreed to be interviewed during the survey. All were immigrants from the Philippines who had come to Sabah for political refuge. The socio demographic of the foreign scavengers was characterised by a low or complete lack of formal education. In developing countries, migrants have performed waste collection and recycling activities such as in India and Egypt (Medina, 2000). The waste pickers are also belong to the poor and marginal to mainstream economy and society (Medina, 2005).All the scavengers interviewed in this study, for whom scavenging was a part-time job, were male. There were no specific hours kept in performing the job, with only one respondent claiming to spend about ten hours a day collecting recyclable items.

The majority of landfill scavengers are indigenous people, mainly from the Kadazan Dusun ethnic group. The local male scavengers are aged between nine and twenty-seven years, while the female scavengers were aged between 30 and 36. In terms of employment issues, most employers in the private sector are only

Table 1. Sociodemographic characteristics of street scavengers in Kota Kinabal

\begin{tabular}{lrr}
\hline \multicolumn{1}{c}{ Characteristics } & Number & Percentage \\
\hline Age & 11 & 55 \\
$15-35$ & 9 & 45 \\
$36-55$ & & \\
Gender & 8 & 40 \\
Male & 12 & 60 \\
Female & & \\
Level of education & 8 & 40 \\
No formal education & 9 & 45 \\
Primary & 3 & 15 \\
Secondary & & \\
Ethnic Group & 13 & 65 \\
Kadazan Dusun & 4 & 20 \\
Malay & 1 & 5 \\
Chinese & 2 & 10 \\
Others & &
\end{tabular}

willing to employ Malaysian citizens so as not to take unnecessary risks by employing illegal immigrants.

\section{Scavenging Location}

The street scavengers group's activities are mostly concentrated at the rubbish bins in major shopping centers in the town, and in the residential area. Other study suggest scavengers (waste picker) collecting solid waste to low cost households area (Katusiimeh, Burger, \& Mol, 2013). Ninety percent of the scavengers operate in small groups of two or three people. About 95\% of them scavenge as a part-time job, half of them also working permanently for $\mathrm{KKCH}$ as a collection crew. Scavengers typically spend between one and six hours a day (or three hours per day on average) collecting materials. The same findings also indicate that the practice of scavenging has become a survival strategy especially for thousands people among the urban poor (Oteng-Ababio, 2012). The group of foreign scavengers was found in very few places, due to their resident status. They tended to concentrate in the city centre (Kota Kinabalu), focusing on the business and bus terminal area. These locations are popular as the centre of public activities, with a considerable amount of litter found scattered everywhere.

The landfill scavengers collecting and separating recyclable materials at landfill site. This group operated at the disposal site in Kayu Madang Sanitary Landfill, the only official site for the final disposal of waste. The total coverage of the area is about $115 \mathrm{~km} 2$ and the site started operating in 1997. The landfill area was built to last up to 15 years, and is used not only for disposal of waste from the Kota Kinabalu area but also for neighbouring areas such as Tuaran, Penampang, Putatan, Kota Belud and Tamparuli. At the landfill site landfill scavengers in this study fall into two groups: those who work with the landfill company and those who are self-employed. Sometimes, large scavenger communities form around the dumps. Many scavengers live and work at dumpsite. The first category is more organised, workers being provided with $\mathrm{T}$-shirts and transportation to and from the landfill site every day. By contrast, those who are self-employed work alone. The routine working hours for organised scavengers are from $7 \mathrm{am}$ until $5 \mathrm{pm}$ from Monday to Friday. Based on the information gathered during the interviews, female scavengers tend to work five days a week, from Monday to Friday, while male scavengers spend the whole week working to increase their income. Compared to the organised scavengers the self-employed were less fortunate, as they did not enjoy any of the facilities provided by the landfill company.

The scavengers' daily routine was noted during the survey trip. Generally they wait for a lorry to unload its waste upon arrival at the landfill site. They then move to the area where the waste is dumped and begin to sort out the recyclables. The majority of local scavengers have come from villages a few kilometres 
from the landfill site. A small number are from further afield, such as those from Papar and Penampang, towns 30-60 km from the site. Groups who live far from the site usually own a temporary shelter built adjacent to the landfill site. These temporary shelters lack basic facilities such as clean water and electricity, providing very poor living conditions for their inhabitants, who return to their home village once a week after receiving their 'salary' for the week or month. Most of them said that the main reason they became involved in scavenging was to earn extra income for the family.In other developing countries living at the sites is normal sight. For instant 20000 scavengers live and work in Calcutta's municipal dumps, 12000 in Manila and 15000 in Mexico City (Medina, 2000).

Although the recycling program is a relatively new phenomenon in the area, the study revealed that some of the scavengers have been involved in scavenging activities for about seven years. This shows that activity related to recycling was already in existence before the program was introduced. Due to their long involvement in this field, the street scavengers know the types of material that are in high demand and that they get a good price for. This is reflected in the amounts of each material (aluminium cans, paper and cardboard) collected by the groups. Aluminium cans (65\% of the material collected) are the most popular items for collection because the price of aluminium is consistently high. The scavengers also collect newspaper and cardboard, which are also in demand, especially by the recycling company. For the foreign scavengers, they tend to focus on collecting aluminum cans. This type of material is collected on the basis of the cost factors and because it is lighter than any other material. The types of materials collected by the landfill scavengers are plastic, paper, aluminium cans, metal and bottles. Other study also revealed the informal collector divert recyclables such as waste metals, plastics, paper and glass for a living (Steuer et al., 2017). Scavenger in Greater Accra, Ghana similarly recovered plastics and metals such as iron, copper and aluminium(Rockson, Kemausuor, Seassey, \& Yanful, 2013). Half of the collected material is sold to a middleman, and the rest is sent directly to the private collection company. Other study also uncovered that materials collected by scavengers was sold to middlemen or recycling industries (Asim, Batool, \& Chaudhry, 2012).

\section{Economic Benefit from Waste Picking}

In identifying the factors that force child immigrants to participate in scavenging, the study revealed financial problems to be the key issue. Some of the scavengers mentioned that, in order to survive, they need to find an income for their family (in addition to their other jobs such as selling local fruit, and that scavenging presents the most convenient opportunity at the present time. A study by Hassan et. al. (2000) reveals that there were about 300 fulltime dumpsite scavengers in selected landfill and that the amount of recyclables collected was between 5,152 to $11,750 \mathrm{~kg}$ per day. In his study of full- and part-time scavengers he found that those in Petaling Jaya separated $12.87 \%$ of newspapers, $31.93 \%$ of glass, $26.98 \%$ of ferrous metal, $4.42 \%$ of nonferrous metal, $3.03 \%$ of plastics and $5.96 \%$ of other material from the total of 476.80 tonnes of rubbish per day. This findings also suggest that scavenging not only delivers recycling rates but also saves the city authorities millions of dollars in avoided waste collection and disposal costs (Wilson, Rodic, Scheinberg, Velis, \& Alabaster, 2012).

As usual, the price obtained for the recyclable material is lower than the market price. This has an impact on the scavenger's daily income that, on average amounts to approximately RM 4.48 ( $£ 0.70)$, with the highest income rising to about RM 13.50 per day (£2.00), for the street scavenger. This was the income generated from selling $7 \mathrm{~kg}$ of various types of paper or $2 \mathrm{~kg}$ of aluminum in the form of cans. On the other hand, the foreign scavengers average daily income

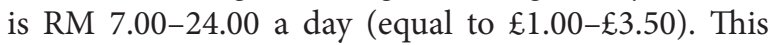
is generated by selling $3-7 \mathrm{~kg}$ of aluminium cans. In the effort to earn more income from scavenging, one scavenger said that sometimes scavengers fight for an item. To avoid these clashes most scavengers from this group prefer to work separately. The average amount of material collected daily by the landfill scavengers is presented in Table 2.

All collected materials are sold at an unfixed price, usually based on the current market price (see Table 2). A scavenger's income is clearly affected by the unstable market prices and can thus be expected to fluctuate from one period to another. On average, most scavengers can expect to earn an income of between RM 200.00 (£30.00) and RM 500.00 ( $£ 70.00)$ a month.Rockson, et.al (2013) revealed, on average scavengers in Ghana earn between US \$7 and US \$17 per day depending on items recovered and market trends. Whereas, Steuer,et. al (2017) in their study in China found that scavenging activities will enable the scavengers to an income around $1,200.00$ (CNY) (\$137.955) to $5250 \mathrm{CNY} \mathrm{( \$ 603.551)}$ per month.

Despite the fact that scavenging is an important element in waste management, the valuable contribution of these groups continues to be only partially recognised. This research found that even though the amount of material collected through scavenging is less than that collected by the private company, the positive impact of scavenging on the environment is significant. For this reason the authority needs to take into account this particular group in designing the waste management system in future.So, it is recommended that the informal sector be recognized as stakeholders within the solid waste management system (Njoroge, Wokabi, Ngetich, \& Kathuri, 2013). Besides contributing to the amount of waste collected, these groups also assist in keeping the town centre clean. Besides this, the scavenging activity has an impact on the economy of the city's poor. The average income generated by the activity, RM 400.00RM 500.00 ( $£ 57.00-£ 71.00)$ a month, is good enough 


\begin{tabular}{|c|c|c|c|c|}
\hline Recyclable material & $\begin{array}{l}\text { Average amount } \\
\quad(\mathrm{kg})\end{array}$ & Price received ${ }^{\star}$ & $\begin{array}{l}\text { Income }(\mathrm{RM}) / \\
\text { month }\end{array}$ & $\mathfrak{E} /$ month \\
\hline $\begin{array}{l}\text { Paper (newspapers, maga-zines, books and } \\
\text { card-board) }\end{array}$ & 200 & $\mathrm{RM} 0.70 / \mathrm{kg}$ & 140.00 & 20.00 \\
\hline Plastic (containers) & $60-80$ & RM 0.10/kg & $6.00-8.00$ & $0.85-1.14$ \\
\hline $\begin{array}{l}\text { Aluminium and other met-al (electronic } \\
\text { goods, cans and containers) }\end{array}$ & $60-90$ & $\mathrm{RM} 2.80 / \mathrm{kg}$ & $168-252$ & $24.0-36.00$ \\
\hline Bottles & $\begin{array}{r}200-250 \\
\text { pieces }\end{array}$ & $\begin{array}{r}\mathrm{RM} 0.05-\mathrm{RM} 0.10(1 \\
\text { piece })\end{array}$ & $10-12.50$ & $1.43-1.79$ \\
\hline
\end{tabular}

for these groups. The involvement of this group in waste management strategy has proved to reduce the cost. Study found that waste picking is not only increase in recycling rates but also saves the city authorities millions of dollars in avoided waste collection and disposal costs (Wilson et al., 2012), contribute to cleaner cities and reduce the volume of waste that has to be dumped (by up to 20 per cent) (Fergutz, Dias, \& Mitlin, 2011). However, government (especially Local Authority-Kota Kinabalu City Hall) was unable to involve this group due to several problems. However, effort to integrate the informal sector with its formal counterparts could improve waste management while addressing health and livelihood issues (Yang, Ma, Thompson, \& Flower, 2018). Recognizing their role, the government should initiate measures that aiming to address the social problems linked to this sector. However, not all attempts have proved successful due barriers preventing their implementation. Lack of knowledge or understanding regarding barriers and kind of measures that may enable formalization (Aparcana, 2017). Some of these problems are also related to waste collection, disposal and financial instability. All these issues have lead to inability of the government / federal government to achieve the sustainable waste management goal in the study area. So, a new waste initiatives should be build on the existing waste management practices being performed by the informal group such as by waste scavengers or waste pickers (Gutberlet et al., 2017). It can be conclude that the integration of the informal waste workers with the formal waste management sector is not a one dimensional or single step process (Masood \& Barlow, 2013)

\section{Conclusion}

Interviews with the scavengers group indicate that the government need to create solution to the waste management problems. To support this, the scavengers group need to be part of the government's attempt to realise its recycling objectives. This study highlights the fact that there is a group of people who depend on waste to survive, and more importantly contribute to the overall waste management program. The contribution of the informal sectors to Kota Kinabalu city's recycling program is an important factor in its success. As recycling is important in protecting the environment it is necessary to highlight the impact of this participation.

\section{References}

Agunwamba, J. C. (2003). Environmental Assessment: Analysis of Scavengers' Activities and Recycling in Some Cities of Nigeria. Environmental Management, 32(1), 116-127. http://doi.org/10.1007/s00267-002-2874-5

Alhumoud, J. M. (2005). Municipal solid waste recycling in the Gulf Co-operation Council states. Resources, Conservation and Recycling, 45(2), 142-158. http://doi. org/https://doi.org/10.1016/j.resconrec.2005.01.010

Aparcana, S. (2017). Approaches to formalization of the informal waste sector into municipal solid waste management systems in low- and middle-income countries: Review of barriers and success factors. Waste Management. http://doi.org/10.1016/j. wasman.2016.12.028

Asim, M., Batool, S. A., \& Chaudhry, M. N. (2012). Scavengers and their role in the recycling of waste in Southwestern Lahore. Resources, Conservation and Recycling, 58, 152-162. http://doi.org/http://dx.doi.org/10.1016/j. resconrec.2011.10.013

Buenrostro, O., \& Bocco, G. (2003). Solid waste management in municipalities in Mexico: goals and perspectives. Resources, Conservation and Recycling, 39(3), 251263. http://doi.org/https://doi.org/10.1016/S09213449(03)00031-4

Department of Statistics Malaysia. (2010). Population Distribution by Local Authority Areas and Mukims. [Internet]. Available from: Retrieved January 22, 2018, from http://www.statistic.gov.my./portal/downloadpopulation/files/population/03/ringkas-kawasan-PBT-

Dias, S. M. (2016). Waste pickers and cities. Environment and Urbanization, 28(2), 375-390. http://doi. org/10.1177/0956247816657302

Ezeah, C., Fazakerley, J. A., \& Roberts, C. L. (2013). Emerging trends in informal sector recycling in developing and transition countries. Waste Manag, 33, 2509-2519. http://doi.org/10.1016/j.wasman.2013.06.020

Fergutz, O., Dias, S., \& Mitlin, D. (2011). Developing urban waste management in Brazil with waste picker organizations. Environment and Urbanization, 23(2), 597-608. http://doi.org/10.1177/0956247811418742

Gutberlet, J., Kain, J.-H., Nyakinya, B., Oloko, M., Zapata, P., \& Zapata Campos, M. J. (2017). Bridging Weak Links of 
Solid Waste Management in Informal Settlements. The Journal of Environment \& Development, 26(1), 106131. http://doi.org/10.1177/1070496516672263

Henry, R. K., Yongsheng, Z., \& Jun, D. (2006). Municipal solid waste management challenges in developing countries - Kenyan case study. Waste Management, 26(1), 92-100. http://doi.org/https://doi.org/10.1016/j. wasman.2005.03.007

Hodal, K. (2017). Living off the landfill: Indonesia's resident scavengers. Retrieved December 20, 2018, from https:// www.theguardian.com/world/2011/sep/27/indonesiawaste-tip-scavengers

Kamel, L. I. (2000). Urban Governance.Informal Sector \& Municipal Solid Waste in Cairo. Retrieved December 28, 2018, from http://www.cerfe.org/public/frhs/00000011. htm

Kamran, A., Chaudhry, M. N., \& Batool, S. A. (2016). Role of the informal sector in recycling waste in Eastern Lahore. Polish Journal of Environmental Studies, 24(2), 537-543.

Kaseva, M. E., \& Gupta, S. K. (1996). Recycling - an environmentally friendly and income generating activity towards sustainable solid waste management. Case study - Dar es Salaam City, Tanzania. Resources, Conservation and Recycling, 17(4), 299-309. http://doi. org/https://doi.org/10.1016/S0921-3449(96)01153-6

Kashyap, P., \& Visvanathan, C. (2014). Formalization of informal recycling in low-income countries. Environmental Science and Engineering (Subseries: Environmental Science), (9789814451727), 41-60. http://doi.org/10.1007/978-981-4451-73-4_3

Katusiimeh, M. W., Burger, K., \& Mol, A. P. J. (2013). Informal waste collection and its co-existence with the formal waste sector: The case of Kampala, Uganda. Habitat International, 38(1), 1-9. http://doi.org/10.1016/j. habitatint.2012.09.002

Malaysia, G. of. (2001). Eight Malaysia Plan 2001-2005. Kuala Lumpur.

Masood, M., \& Barlow, C. Y. (2013). Framework for integration of informal waste management sector with the formal sector in Pakistan. Waste Management and Research, 31(10 SUPPL.), 93-105. http://doi. org/10.1177/0734242X13499811

McBean, E. A., del Rosso, E., \& Rovers, F. A. (2005). Improvements in financing for sustainability in solid waste management. Resources, Conservation and Recycling, 43(4), 391-401. http://doi.org/https://doi. org/10.1016/j.resconrec.2004.06.009

Medina, M. (2000). Scavenger cooperatives in Asia and Latin America. Resources, Conservation and Recycling, 31(1), 51-69. http://doi.org/https://doi.org/10.1016/S09213449(00)00071-9

Medina, M. (2005). Waste Picker Cooperatives in Developing Countries: Paper prepared for WIEGO/Cornell/SEWA Conference on Membership-Based Organizations of the Poor. Membershipbased organizations of the poor.

Mohamad Taha, M. P. (2018). Integrated Solid Waste Management: Challenge And Future. Retrieved from http://nehapmalaysia.moh.gov.my/wp-content/ uploads/2016/03/Paper-2-Solid-Waste.pdf

Muttamara, S. (1994). Solid Waste Recycling And Reuse In Bangkok. Waste Management \& Research, 12(2), 151163. http://doi.org/10.1006/wmre.1994.1005

Njoroge, K. S., Wokabi, M. S., Ngetich, K., \& Kathuri, M. N. (2013). Influence of Informal Solid Waste Management on Livelihoods of Urban Solid Waste Collectors : A Case
Study of Nakuru Municipality. International Journal of Humanities and Social Science, 3(13), 95-108.

Oteng-Ababio, M. . (2012). The role of the informal sector in solid waste management in the Gama, Ghana: Challenges and opportunities. Tijdschrift Voor Economische En Sociale Geografie, 103(4), 412-425. http://doi. org/10.1111/j.1467-9663.2011.00690.x

Pacheco, M. (1994). Recycling in Bogota: developing a culture for urban sustainability. Environment \& Urbanisation, $4(2)$.

Rockson, G. N. K., Kemausuor, F., Seassey, R., \& Yanful, E. (2013). Activities of scavengers and itinerant buyers in Greater Accra, Ghana. Habitat International, 39, 148-155. http://doi.org/http://dx.doi.org/10.1016/j. resconrec.2014.05.006

Rouse, J. R. (2006). Seeking common ground for people: Livelihoods, governance and waste. Habitat International, 30(4), 741-753. http://doi.org/https://doi.org/10.1016/j. habitatint.2005.09.001

Sasaki, S., \& Araki, T. (2014). Estimating the possible range of recycling rates achieved by dump waste pickers: The case of Bantar Gebang in Indonesia. Waste Management and Research, 32(6), 474-481. http://doi. org/10.1177/0734242X14535651

Scheinberg, A. (2012). Informal Sector Integration and High Performance Recycling: Evidence from 20 Cities. WIEGO Working Paper (Vol. 23).

Soerjani, M. (1984). Present waste management in cities in Indonesia. Conservation \& Recycling, 7(2), 141148. http://doi.org/https://doi.org/10.1016/03613658(84)90011-0

Steuer, B. . b, Ramusch, R. ., Part, F. ., \& Salhofer, S. . (2017). Analysis of the value chain and network structure of informal waste recycling in Beijing, China. Resources, Conservation and Recycling, 117, 137-150. http://doi. org/10.1016/j.resconrec.2016.11.007

Supriyadi, S., Kriwoken, L. K., \& Birley, I. (2000). Solid waste management solutions for Semarang, Indonesia. Waste Management \& Research, 18(6), 557-566. http://doi. org/10.1177/0734242X0001800606

Tirado-Soto, M. M., \& Zamberlan, F. L. (2013). Networks of recyclable material waste-picker's cooperatives: An alternative for the solid waste management in the city of Rio de Janeiro. Waste Management, 33(4), 1004-1012. http://doi.org/10.1016/j.wasman.2012.09.025

Wilson, D. C., Rodic, L., Scheinberg, a., Velis, C. a., \& Alabaster, G. (2012). Comparative analysis of solid waste management in 20 cities. Waste Management \& Research, 30(3), 237-254. http://doi. org/10.1177/0734242X12437569

Wilson, D. C., Velis, C., \& Cheeseman, C. (2006). Role of informal sector recycling in waste management in developing countries. Habitat International. http://doi. org/10.1016/j.habitatint.2005.09.005

Yang, H., Ma, M., Thompson, J. R., \& Flower, R. J. (2018). Waste management, informal recycling, environmental pollution and public health. Journal of Epidemiology and Community Health, 72(3), 237-243. http://doi. org/10.1136/jech-2016-208597

Zurbrügg, C., Drescher, S., Patel, A., \& Sharatchandra, H. C. (2004). Decentralised composting of urban waste - An overview of community and private initiatives in Indian cities. Waste Management. http://doi.org/10.1016/j. wasman.2004.01.003 